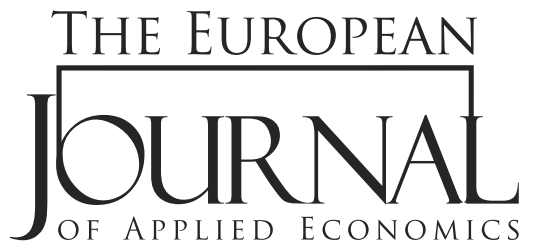

EJAE 2018, 15(1): 38-45

ISSN 2406-2588

UDK: $336.27(439)$

336.277:336.143

DOI: 10.5937/EJAE15-15684

Original paper/Originalni naučni rad

\title{
TEST OF A QUADRATIC RELATIONSHIP BETWEEN AGGREGATE OUTPUT AND GOVERNMENT DEBT IN HUNGARY
}

\author{
Yu Hsing \\ College of Business, Management and Business Administration, \\ Southeastern Louisiana University, USA
}

\begin{abstract}
:
The study which applies extended model of aggregate demand and aggregate supply (AD/AS) and uses a quarterly sample during the period from 2001 (Q1) till the last quarter of 2015, has shown that real GDP in Hungary exhibits a bell-shaped quadratic relationship with government debt as a percent of GDP (DY), direct relationship with the real effective exchange rate (ER), stock market price (SP) and the real crude oil price (OP), and an inverse relationship with the real government bond yield (IR) and the expected inflation rate (EI). The critical value of government debt as a percent of GDP is estimated to be $69.22 \%$, which is higher than the EU criterion of $60.00 \%$ but less than the threshold of $90.00 \%$ proposed by Reinhart and Rogoff (2010).
\end{abstract}

\section{Article info:}

Received: November 14, 2017

Correction: January 24, 2018

Accepted: January 24, 2018

\section{Keywords:}

government debt as a percent of GDP, real exchange rates, $\mathrm{i}$

nterest rates,

stock prices,

oil price.

\section{INTRODUCTION}

The economy of Hungary shows both - signs of encouragement and concern. Real GDP declined by $6.56 \%$ in 2009 due to the global financial crisis, but showed positive growth of $2.00 \%$ or more since 2013. Due to the adoption of inflation targeting in 2001, its inflation rate has continued to improve and has been below 3.00\% since 2013. The unemployment rate reached the peak of $11.25 \%$ in 2010 because of the lingering impact of the global financial crisis, and has displayed improvements as evidenced by the declining unemployment rate of less than $5.00 \%$ since 2016 . Relatively prudent fiscal policy was demonstrated by the declining government borrowing-to-GDP ratio of less than $3.00 \%$ since 2007 . The current account balance has exhibited positive values since 2010 and it has been greater than 3.00\% since 2015. A matter of major concern is a relatively high government debt as a percent of GDP changing from a low value of $51.70 \%$ in 2001 to a high value of $80.667 \%$ in 2011 . Although it has declined to below $75.00 \%$ since 2015, it is still higher than the EU threshold of $60.00 \%$. 
This study examines the effects of the government debt-to-GDP ratio and other related economic variables on real GDP in Hungary. The study applies an extended AD/AS model and estimates a reduced-form equation. An increase in debt-financed government spending tends to shift AD rightward. However, the crowding-out effect of a higher real interest rate, triggered by higher government debt, tends to reduce consumption and investment expenditures and shift AD leftward. Rising government debt might be beneficial to aggregate output, but this needs to be tested empirically. A quadratic form is employed to detect whether a nonlinear relationship between aggregate output and government debt as a percent of GDP may exist. The critical value is the government debt as a percent of GDP corresponding to the maximum value of real output. To the left of the critical value, real output and government debt as a percent of GDP has a direct relationship whereas to the right of the critical value, real output and government debt as a percent of GDP have an inverse relationship. Potential impacts of real currency depreciation and supply shocks are incorporated in the model as well.

\section{LITERATURE REVIEW}

Whether more government debt may affect aggregate output depends on its potential effect on the real interest rate, which would affect private spending. More government debt-financed spending tends to shift aggregate demand to the right and increase aggregate output in the short run. The positive effect on real output may be cancelled out partially or completely by the negative impact on consumption and investment spending due to a higher real interest rate in the long run. There have been several recent studies examining the effect of expansionary fiscal policy on the real interest rate or aggregate output for Hungary and other related countries.

Based on a sample of 31 emerging and advanced countries during 1980-2008, Baldacci and Kumar (2010) show that higher government/public debt and deficit cause the long-term increase of the interest rate, including the sovereign bond yield. The specific magnitude depends on initial structural, fiscal and institutional conditions.

Using a sample of 54 countries including Hungary during 1990-2009, López, Riquelme and Muñoz (2011) reveal that a $1.00 \%$ rise in the government deficit causes the long-term interest rate to rise by 10.00 to 12.00 basis points, and that approximately $40.00 \%$ of the change in the long-term interest rate in G7 countries can be explained by fiscal policy. Furthermore, fiscal rules reduce the impact of the deficit on long-term rate, and more credibility of a central bank leads to a lower interest rate due to lower inflation expectations.

Based on a sample of G7 countries during 1960-2005, Hauner and Kumar (2011) show that higher government deficits raise the long-term interest rate, but the effect is relatively small and that there is no structural break in interest rate determination during the sample period.

Gruber and Kamin (2012) study the effect of expansionary fiscal policy on the long-term rate for OECD countries during 1988-2007. They find that the deterioration of fiscal position raises the U.S. bond yield by 60.00 base points, and the bond yield by a smaller magnitude in other G7 countries.

Claeys, Moreno and Suriñach (2012) examine the effect of fiscal policy on the interest rate based on a sample of 46 countries including Hungary during 1990-2005. They indicate that the crowding-out effect is relatively small because $1.00 \%$ increase in the government debt ratio leads to an increase in the domestic interest rate by 2.00 percentage points at the most. The effect is smaller among OECD or EU countries due to global financial integration and larger in emerging countries due to less financial integration. 
Ağca and Celasun (2012) reveal that a rising external public debt leads to a higher corporate borrowing cost whereas a higher domestic public debt does not affect corporate borrowing cost in 15 emerging countries including Hungary, and that countries with past default incidents or frail creditor rights tend to have a higher correlation.

Aisen and Hauner (2013) investigate the effect of government budget deficits on the interest rate using a sample of 60 advanced and emerging countries including Hungary during 1970-2006. They show that more budget deficits raise the interest rate if a country has high deficits, high domestic government debt, low financial openness, low financial depth, liberalized interest rate, or high domestic financing.

\section{THE MODEL}

We can express extended AD/AS model (Hsing, 2016, 2017a, 2017b) as follows:

$$
\begin{aligned}
& A D=w(I F, G S, G T, I R, S P, E R) \\
& A S=z(I F, E R, O P, . E I)
\end{aligned}
$$

where AD, IF, GS, GT, IR, SP, ER, AS, OP and EI stand for aggregate demand or aggregate output demanded, the inflation rate, real government spending, real government tax revenue, the real interest rate, the stock market index, the real effective exchange rate, short-run aggregate supply or aggregate output supplied, real oil price per barrel, and the expected inflation rate.

By solving aggregate output and IF simultaneously, we can find equilibrium aggregate output (Y) as:

$$
Y^{*}=f(G S-G T, E R, I R, S P, E O P, E I)
$$

As investors are more concerned about potential default of government debt, which is an accumulation of the government deficit, we replace GS - GT with the government debt-to-GDP ratio (DY):

$$
\begin{gathered}
Y^{*}=h(D Y, E R, I R, S P, O P, E I) \\
? \quad ? \quad-\quad+\quad ? \quad-
\end{gathered}
$$

The sign beneath each of the independent variables is the hypothesis to be tested. Real depreciation tends to stimulate exports, impair imports, increase import prices and domestic inflation, and reduce capital inflows. Conversely, currency appreciation is expected to impair exports, increase imports, reduce import prices and domestic inflation, and increase capital inflows. The net effect needs to be tested and determined empirically.

Previous studies including Hungary and other related countries show different findings. According to Bahmani-Oskooee and Kutan (2008), currency depreciation has a negative effect on real GDP in the short run; Miteza (2006), Kalyoncu, Artan, Tezekici and Ozturk (2008) state its negative impact on real GDP in the long run whereas Nusair (2014) argues that currency depreciation has positive effect on real GDP in the long run. A neutral effect of currency depreciation is determined in the studies run by Bahmani-Oskooee and Kutan ( 2008) 
A higher real oil price is expected to reduce short-run AS and aggregate output. Nonetheless, a rising real oil price triggered by strong $\mathrm{AD}$ tends to increase $\mathrm{AD}$. Therefore, the net impact is unclear (Hamilton, 1996; Kilian, 2014a, 2014b).

Figure 1 shows that a nonlinear relationship between aggregate output and the government debtto-GDP ratio may exist. The nonlinear relationship may be described by a quadratic form:

$$
\begin{gathered}
Y^{*}=v\left(D Y, D Y^{2}, E R, I R, S P, O P, E I\right) \\
+\quad-\quad ?-\quad+\quad ?-
\end{gathered}
$$

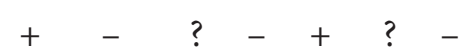

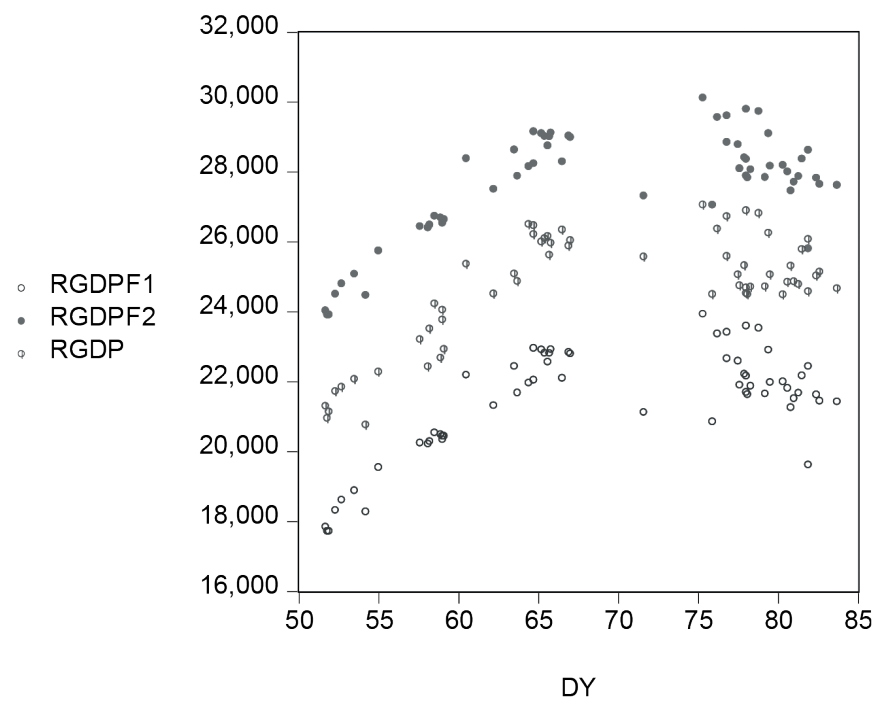

Figure 1 - Scatter diagram between real GDP and government debt as a percent of GDP (DY) Notes: RGDP is actual real GDP. RGDPF1 and RGDPF2 are the fitted real GDP at the $95.00 \%$ interval.

Taking the partial derivative of the dependent variable with respect to DY and setting the equation equal to zero, we find the critical value of government debt as a percent of GDP corresponding to the maximum aggregate output as:

$$
D Y^{*}=\theta_{1} / 2 \theta_{2}
$$

where $\theta_{1}$ and $\theta_{2}$ are the estimated coefficients for DY and DY2.

\section{EMPIRICAL RESULTS}

The sources of the data came from the Eurostat, the Bank of Hungary, and IMF's International Financial Statistics. Aggregate output in real terms is measured in million forints. This study uses the amount of real GDP instead of the growth rate of real GDP as the dependent variable as equilibrium real GDP instead of the growth rate of real GDP is derived from the AD/AS model. General government debt is measured as a percent of GDP. A higher real effective exchange rate suggests real appreciation of the forint. The real interest rate is represented by the difference between the government bond yield and 
the expected inflation rate. The equity index is selected to represent the stock market index. The real oil price per barrel is calculated as the nominal oil price per barrel adjusted by the CPI and is measured in the forint. The lagged real oil price is used in order to consider potential impact lag of the real oil price on aggregate output and to reduce the problems caused by a high degree of multicollinearity among independent variables. These problems include the change in the signs and insignificance of the coefficients. The mean value of the past four inflation rates is used to represent the expected inflation rate. The sample has a total of 60.00 observations ranging from 2001.Q1 to 2015.Q4. The data for the government bond yield before 2001.Q1 are unavailable. Descriptive statistics are presented in the Appendix.

The augmented Dickey-Fuller test reveals that each time series variable has a unit root in level and is stationary in first difference. To test whether these time series variables have a long-term stable relationship, the augmented Dickey-Fuller unit root test of the regression residual reveals that the critical value of -3.55 is less than the test statistics of -3.88 in absolute values. As a result, these variables are cointegrated.

Table 1 presents empirical results. The exponential GARCH model is used in empirical work because it can detect and correct potential autoregressive conditional heteroscedasticity and because it has less restrictions in the variance equation. Approximately $87.84 \%$ change in the dependent variable can be explained by theexogenous variables. All the estimated coefficients are found to be significant at the $1.00 \%$ or $2.50 \%$ level. Aggregate output has a bell-shaped quadratic relationship with DY, a positive relationship with ER, SP and the lagged OP, and a negative relationship with IR and EI.

The critical value based on equation (5) is estimated to be $69.22 \%$, suggesting that aggregate output and DY have a direct relationship when the government debt-to-GDP ratio is less than $69.22 \%$ and an inverse relationship when the ratio is higher than $69.22 \%$. The critical value of $69.22 \%$ is less than the $90.00 \%$ threshold proposed by Reinhart and Rogoff (2010) but higher than the EU criterion of $60.00 \%$.

\begin{tabular}{|c|c|c|}
\hline Variable & Coefficient & z-Statistic \\
\hline $\mathrm{C}$ & -5523.01 & -20.34 \\
\hline DY & 859.48 & 1935.51 \\
\hline $\mathrm{DY}^{\wedge} 2$ & -6.21 & -437.91 \\
\hline ER & 12.16 & 2.90 \\
\hline IR & -172.96 & -6.37 \\
\hline SP & 22.28 & 26.84 \\
\hline $\mathrm{OP}_{\mathrm{t}-1}$ & 0.01 & 2.47 \\
\hline EI & -365.83 & -16.26 \\
\hline R-squared & 0.88 & \\
\hline Adjusted R-squared & 0.86 & \\
\hline Akaike info criterion & 15.14 & \\
\hline Schwarz criterion & 15.49 & \\
\hline Methodology & EGARCH & \\
\hline Sample period & 2001.Q1 - 2015.Q4 & \\
\hline Number of observations & 60.00 & \\
\hline Mean absolute percent error & $1.60 \%$ & \\
\hline
\end{tabular}

Table 1- Estimated regression of aggregate output for Hungary 
Notes: As the real interest rate, the expected inflation rate and the binary variables have zero or negative values, these 3 variables cannot be transformed into the log scale. The choice of the linear form is mainly to make the interpretation of the results easier, because, except for the intercept binary variable, all the estimated coefficients are the slopes. The variables are defined as follows:

$\mathrm{Y}=$ aggregate output,

$\mathrm{DY}=$ the government debt-to-GDP ratio,

$\mathrm{ER}=$ the real effective exchange rate,

$\mathrm{IR}=$ the real interest rate,

$\mathrm{SP}=$ the stock price,

$\mathrm{OP}=$ the real oil price, and

$\mathrm{EI}=$ the expected inflation rate.

The positive and significant coefficient of ER implies that real appreciation raises aggregate output and that the positive impacts of real appreciation such as potential lower inflation and capital inflows dominate the negative effect such as less export. The positive and significant coefficient of SP implies that rising stock prices increase household wealth, consumption spending, and aggregate demand.

Several different regressions were estimated. When the log scale is used except for the real government bond yield, the expected inflation rate and the binary variable with zero or negative values, the value of R-squared is $90.41 \%$, but the positive coefficients of ER and OP become insignificant at the $10.00 \%$ level. The critical value corresponding to the maximum aggregate output is estimated to be $68.62 \%$, which is slightly less than the $69.22 \%$ when the linear form is chosen in Table 1 . The interactive and intercept binary variables are applied to analyze the relationship between aggregate output and DY. A binary variable having a value of 0 during 2001.Q1 - 2008.Q4 and 1 during 2009.Q1 - 2015.Q4 is created. The value of $\mathrm{R}$-squared is calculated to be 0.88 . The positive coefficient during 2001.Q1 2008.Q4 and the negative coefficient during 2009.Q1 - 2015.Q4 are both significant at the $1.00 \%$ level. On the other hand, the estimated positive coefficient of SP becomes insignificant at the $10.00 \%$ level.

\section{CONCLUSIONS}

This paper has studied the impact of government debt and other variables on aggregate output. When government debt as a percent of GDP is less than $69.22 \%$, the relationship is positive whereas when government debt as a percent of GDP is greater than $69.22 \%$, the relationship is negative. In addition, a higher ER, a lower IR, a higher SP, a higher OP or a lower EI increases aggregate output. In comparison, the $69.22 \%$ critical value for Hungary is slightly higher than the $60 \%$ threshold for the EU countries but lower than the $90 \%$ threshold proposed by Reinhart and Rogoff (2010).

In comparison, the negative relationship between government debt as a percent of GDP and real GDP in this article are consistent with previous findings by Baldacci and Kumar (2010), Hauner and Kumar (2011), López, Riquelme and Muñoz (2011), Gruber and Kamin (2012), Ağca and Celasun (2012),Claeys, Moreno and Suriñach (2012) and Aisen and Hauner (2013) when government debt as a percent of GDP is greater than the critical value of $69.22 \%$. But the results cannot be compared with previous findings when the debt-to-GDP ratio is less than the critical value of $69.22 \%$, because they do not estimate a critical value of government debt as a percent of GDP. The finding of the critical value of government debt as a percent of GDP for Hungary may provide some insights into the subject for 
some EU countries such as Greece, Italy, Portugal and Spain with relatively high government debt as a percent of GDP. A case study of each of these countries may find the critical value and provide policymakers guidelines in reviewing and improving fiscal policy.

The Hungarian government may need to exercise caution in order to reduce potential negative impacts of a higher Debt-to-GDP ratio on aggregate output. Fortunately, its debt-to-GDP ratio declined from the peak value of $83.70 \%$ in $2010 . \mathrm{Q} 2$ to $73.50 \%$ in 2015 .Q4 . The declining real effective exchange rate from the peak value of 110.00 in 2008.Q3 to 88.00 in 2015.Q4 would impede aggregate output. In addition, to continue pursuing economic growth, the Hungarian government needs to maintain a lower real cost of borrowing, a stable and strong stock market, and a lower expected inflation rate so that households and firms would have a lower borrowing cost and more wealth to increase consumption and investment expenditures, and short-run aggregate supply would shift rightward, leading to a higher real GDP.

\section{REFERENCES}

\section{REFERENCES}

Ağca, Ş., \& Celasun, O. (2012). Sovereign debt and corporate borrowing costs in emerging markets. Journal of International Economics, 88(1), 198-208. DOI: 10.1016/j.jinteco.2012.02.009

Aisen, A., \& Hauner, D. (2013). Budget deficits and interest rates: a fresh perspective. Applied Economics, 45(17), 2501-2510. DOI: $10.1080 / 00036846.2012 .667557$

Bahmani-Oskooee, M., \& Kutan, A. M. (2008). Are devaluations contractionary in emerging economies of Eastern Europe? Economic Change and Restructuring, 41(1), 61-74. DOI: 10.1007/s10644-008-9041-9

Baldacci, E., \& Kumar, M. S. (2010). Fiscal deficits, public debt, and sovereign bond yields. Washington, DC: International Monetary Fund.

Claeys, P., Moreno, R., \& Suriñach, J. (2012). Debt, interest rates, and integration of financial markets. Economic Modelling, 29(1), 48-59. DOI: 10.1016/j.econmod.2011.05.009

Gruber, J. W., \& Kamin, S. B. (2012). Fiscal positions and government bond yields in OECD. countries. Journal of Money, Credit and Banking, 44(8), 1563-1587. DOI: 10.1111/j.1538-4616.2012.00544.x

Hamilton, J. D. (1996). This is What Happened to the Oil Price-Macroeconomy Relationship. Journal of Monetary Economics, 38(2), 215-220. DOI: 10.1016/S0304-3932(96)01282-2

Hauner, D., \& Kumar, M. S. (2011). Interest rates and budget deficits revisited-evidence from the G7 countries. Applied Economics, 43(12), 1463-1475. DOI: 10.1080/00036840802600574

Hsing, Y. (2016). Is real depreciation contractionary? The case of South Korea. Economics Bulletin, 36(4), 19511958. DOI: $10.22606 /$ jaef.2016.11002

Hsing, Y. (2017a). Is real depreciation or more government deficit expansionary? The case of Slovenia. South East European Journal of Economics and Business, 12(1), 50-56. DOI: 10.1515/jeb-2017-0005

Hsing, Y. (2017b). Is more government debt or currency depreciation expansionary? The case of Poland. Theoretical and Applied Economics, 3(612), 63-70.

Kalyoncu, H., Artan, S., Tezekici, S., \& Ozturk, I. (2008). Currency devaluation and output growth: an empirical evidence from OECD. countries. International Research Journal of Finance and Economics, 14(2), 232-238.

Kilian, L. (2008). The economic effects of energy price shocks. Journal of Economic Literature, 46(4), 871-909. DOI: $10.1257 /$ jel.46.4.871

Kilian, L. (2009). Not all oil price shocks are alike: Disentangling demand and supply shocks in the crude oil market. American Economic Review, 99(3): 1053-69. DOI: 10.1257/aer.99.3.1053 
López, E., Riquelme, V., \& Muñoz, E. (2011). Long-term interest rate and fiscal policy. Documentos de Trabajo, 633(1). Santiago: Banco Central de Chile.

Miteza, I. (2006). Devaluation and output in five transition economies: a panel cointegration approach of Poland, Hungary, Czech Republic, Slovakia and Romania, 1993-2000. Applied Econometrics and International Development, 6(1), 77-86.

Nusair, S. A. (2014). Are devaluations expansionary or contractionary in transition economies? Applied Economics Quarterly, 60(3), 215-251. DOI: 10.3790/aeq.60.3.215

Reinhart, C. M., \& Rogoff, K. S. (2010). Debt and growth revisited. MPRA Paper 24376. Retrieved September 16, 2017, from https://mpra.ub.uni-muenchen.de/24376/1/MPRA_paper_24376.pdf

\section{APPENDIX - DESCRIPTIVE STATISTICS}

\begin{tabular}{lccccccc}
\hline & Y & DY & ER & IR & SP & OP $_{\mathrm{t}-1}$ & EI \\
Mean & 24668.92 & 69.24 & 93.44 & 2.09 & 76.17 & 22810.85 & 4.90 \\
Median & 24861.95 & 66.9 & 94.11 & 2.52 & 82.02 & 22488.21 & 4.93 \\
Maximum & 27051.60 & 83.70 & 110.39 & 5.15 & 124.50 & 36181.17 & 10.26 \\
Minimum & 20752.10 & 51.70 & 72.93 & -2.50 & 28.37 & 10742.01 & -0.49 \\
Std. Dev. & 1620.36 & 10.38 & 7.59 & 1.97 & 26.60 & 7428.73 & 2.56 \\
Skewness & -0.85 & -0.23 & -0.45 & -0.67 & -0.44 & 0.07 & -0.15 \\
Kurtosis & 2.91 & 1.59 & 3.13 & 2.64 & 2.02 & 1.69 & 3.20 \\
Jarque-Bera & 7.22 & 5.47 & 2.05 & 4.87 & 4.37 & 4.33 & 0.25 \\
Probability & 0.03 & 0.07 & 0.36 & 0.9 & 0.11 & 0.11 & 0.88 \\
Sum & 1480135.00 & 4154.20 & 5606.41 & 125.12 & 4570.38 & 1368651.00 & 294.20 \\
Sum Sq. Dev. & $1.55 \mathrm{E}+08$ & 6359.70 & 3400.99 & 229.69 & 41732.73 & $3.26 \mathrm{E}+09$ & 386.57 \\
Observations & 60.00 & 60.00 & 60.00 & 60.00 & 60.00 & 60.00 & 60.00 \\
\hline
\end{tabular}

\section{ISPITIVANJE KVADRATNE RELACIJE AGREGATNOG AUTPUTA I DRŽAVNOG DUGA U MAĐARSKOJ}

\section{Rezime:}

Primenom proširenog modela agregatne tražnje i agregatne ponude (AD / AS) i korišćenjem kvartalnog uzorka za period 2001.K1-2015.K4, ova studija pokazuje da stvarni BDP u Mađarskoj ispoljava kvadratnu vezu zvonastog oblika gledano prema državnom dugu koji se iskazuje kao procenat BDP-a, zatim odnos direkthe zavisnosti od stvarnog efektivnog deviznog kursa, berzanske cene i stvarne cene nafte; dok je relacija u odnosu na stvarni prinos od državnih obveznica i očekivane stope inflacije inverzna. Procenjuje se da je kritična vrednost državnog duga iskazanog u vidu procenta BDP-a $69.22 \%$, što predstavlja veću vrednost u odnosu na kriterijum EU od 60\%, ali znatno manju u odnosu na prag od 90\% koji predlažu autori Reinhart i Rogoff (2010).

Ključne reči:

javni dug kao procenat BDP-a, realni devizni kurs,

kamatna stopa, vrednost akcija, cena nafte. 